\title{
Décimas, payas, poemas y canciones en homenaje al desaparecido profesor Alberto Moreira
}

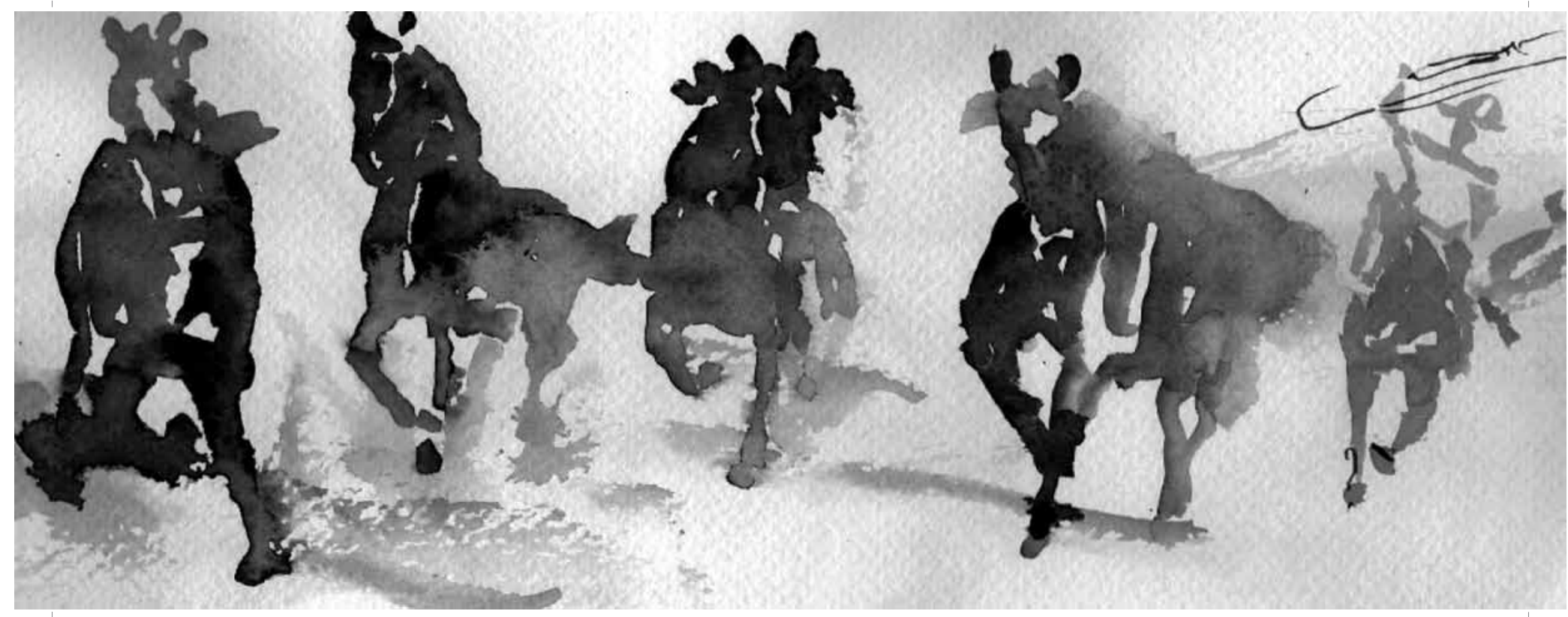

"Yo quisiera relatar lo que sé de don Alberto que fue un hombre correcto, un arquitecto puro y honesto».

Con palabras simples, pero cargadas de sentimientos, en formas de poemas y Cantos a lo Humano y a lo Divino, además de cuecas interpretadas por el grupo Aparcoa, conjunto folclórico icono de la FAU; los numerosos amigos, profesores, autoridades, familiares, campesinos, niños, y mujeres rindieron un esplendido homenaje póstumo al querido profesor de nuestra Facultad, Alberto Moreira, fallecido en el invierno pasado. La jornada organizada por el Profesor Fernán Meza vistió de campo por algunas horas los patios de la FAU, que vio llegar hasta sus aulas a decenas de huasos ataviados con sus mantas y aperos, montando sus pingos, para decir presente en nombre del Club de Huasos La Villita, de Isla de Maipo, comuna de donde era don Alberto, y Club al que perteneció como socio fundador.

Desde el alcalde de Isla de Maipo, David Morales, pasando por los concejales y otras altas autoridades del municipio, personalidades como el ex Presidente del Colegio de Arquitectos Don Mario Paredes, el distinguido Abogado y ex Diputado Luis Valentín Ferrada, hasta funcionarios de la FAU que conocieron y quisieron a Alberto Moreira, desearon acompañar a su viuda, Cecilia, quien presidió el homenaje.
Su hijo Tito, vestido con elegante tenida huasa, ofició de maestro de ceremonias y presentador en la fiesta que por momentos parecía devolver a don Alberto a la vida. En efecto, un gran mural con la imagen del desaparecido arquitecto, retratado con sombrero y traje huaso, fue uno de los iconos más sobresalientes de la jornada, junto a las numerosa otras muestras de cariño, que se presentaron como forma de respeto a su memoria. Entre ellas, una muestra de sus acuarelas, con imágenes de caballos, ejemplares que tanto amó el profesor Moreira. Asimismo un desfile con las más nobles tradiciones y costumbres campesinas de las que Moreira era un amante apasionado.

Tampoco estuvo ausente el Decano, Julio Chesta, que en todo momento acompañó a la señora Cecilia y numerosos profesores, autoridades académicas y secretarias, quienes guardan un especial cariño por don Alberto, ante las diversas atenciones que siempre tuvo hacia ellas.

Varias veces durante el acto se recordó aquella frase que retrata cabalmente a Alberto Moreira y que él siempre repetía, especialmente a los miembros más pequeños del Club de Huasos de La Villita: «Ser Huaso es ser un Caballero». 